\title{
First record of Hyposoter placidus (DESVIGNES, 1856) (Hymenoptera: Ichneumonidae) in Poland: the specialized parasitoid of Lycaena FABRICIUS, 1807 butterflies (Lepidoptera: Lycaenidae)
}

\author{
MARCin SiElEZNIEW*, AgAtA Kostro-AmbroZiaK \\ Laboratory of Insect Evolutionary Biology and Ecology, Institute of Biology, \\ University of Bialystok, Ciołkowskiego 1J, PL-15-245 Białystok, Poland
}

\begin{abstract}
Adult ichneumonids of Hyposoter placidus were reared from caterpillars of the large copper butterfly Lycaena dispar collected in NE Poland, feeding on Rumex confertus, $R$. hydrolapathum and $R$. obtusifolius. This is the first record of this parasitoid in the country. We hypothesize that $H$. placidus may be a factor limiting the abundance of populations of $L$. dispar, a widespread species but usually occurring in low numbers.
\end{abstract}

KEY WORDS: Campopleginae, endoparasitoid, koinobiont, larval parasitoid, Lycaena dispar.

\section{INTRODUCTION}

The large Campopleginae subfamily of parasitoid wasps (Hymenoptera, Ichneumonidae) includes mostly solitary koinobiont endoparasitoids of holometabolous insects (QUICKE 2015). The vast majority of them parasitize Lepidoptera, and the genus Hyposoter FÖRSTER, 1869, with about 120 species, is a typical example (YU et al. 2012). Some species of the genus, e.g. H. didymator (THUNBERG, 1822) and H. ebeninus (GRAVENHORST, 1829), are natural enemies of serious agricultural pests (see e.g. MEDINA et al. 2007, HARVEY et al. 2010).

Females of Hyposoter oviposit into young caterpillars, which in some cases are still unhatched, e.g. H. horticola (GRAVENHORST, 1829) infests clutches of eggs of Melitaea cinxia (LinNAEUS, 1758) (CASTELO et al. 2010). Hosts are usually killed in the penultimate

*Corresponding author: marcins@uwb.edu.pl 
larval instar and the end of the parasitoid's development is quite peculiar: in contrast to many other ichneumonid wasps, larvae of Hyposoter do not leave their hosts but pupate inside their skin - their spotted cocoons may be even visible through it (SHAw et al. 2009).

A total of 28 Hyposoter species have been recorded from Poland so far (YU et al. 2012). In the present paper, we document for the first time the presence of $H$. placidus (DESVIGNES, 1856) in the country with some remarks on the relationship with its host, the large copper butterfly Lycaena dispar (HAWORTH, 1802) (Lepidoptera: Lycaenidae).

\section{MATERIALS AND METHODS}

Twenty caterpillars of the large copper butterfly Lycaena dispar, feeding on Rumex confertus WILLD., were collected in the southern outskirts of Białystok (NE Poland) (N53 $\left.06^{\prime} 39^{\prime \prime}, \mathrm{E} 23^{\circ} 05^{\prime} 55^{\prime \prime}\right)$ on 5-8 May 2015. They were reared at room temperature in plastic containers and fed with Rumex leaves.

The adult parasitoids reared from $L$. dispar caterpillars were identified on the basis of the draft key to the genus Hyposoter (K. Horstmann, unpublished). The voucher specimens are in the authors' collections, which are deposited at the Institute of Biology, University of Bialystok.

\section{RESULTS}

The reared caterpillars varied in size (Fig. 1): the twelve larger ones pupated quickly, whereas while the other eight grew little, eventually, at the end of the third instar, becoming immobile. Superficially, they resembled those preparing to pupate, but they were considerably smaller (Fig. 2). After a few days, their colour turned brown and finally black - this resembled a fungal infection (Fig. 3). The skin also hardened. After another two weeks, Hyposoter placidus adults (Fig. 5 and 6) emerged from the mummified larvae (always as a solitary parasitoid), leaving a large hole (Fig. 4). The emerged butterflies were released at the sites of origin.

Some larvae of $L$. dispar parasitized by $H$. placidus were also collected on Rumex obtusifolius L. at Uhowo near the Narew National Park (N52 59 '51" E22 $\left.{ }^{\circ} 56^{\prime} 23^{\prime \prime}\right)$, on $R$. hydrolapathum Huds. at Brzeziny near the Biebrza National Park (N5314'50",

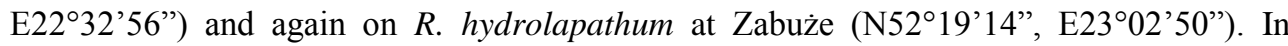
addition, an 'empty' mummified caterpillar was found on $R$. hydrolapathum at Górne (N54¹5'37" E22 $\left.{ }^{\circ} 26^{\prime} 24^{\prime \prime}\right)$ near Gołdap in mid-August 2013. 


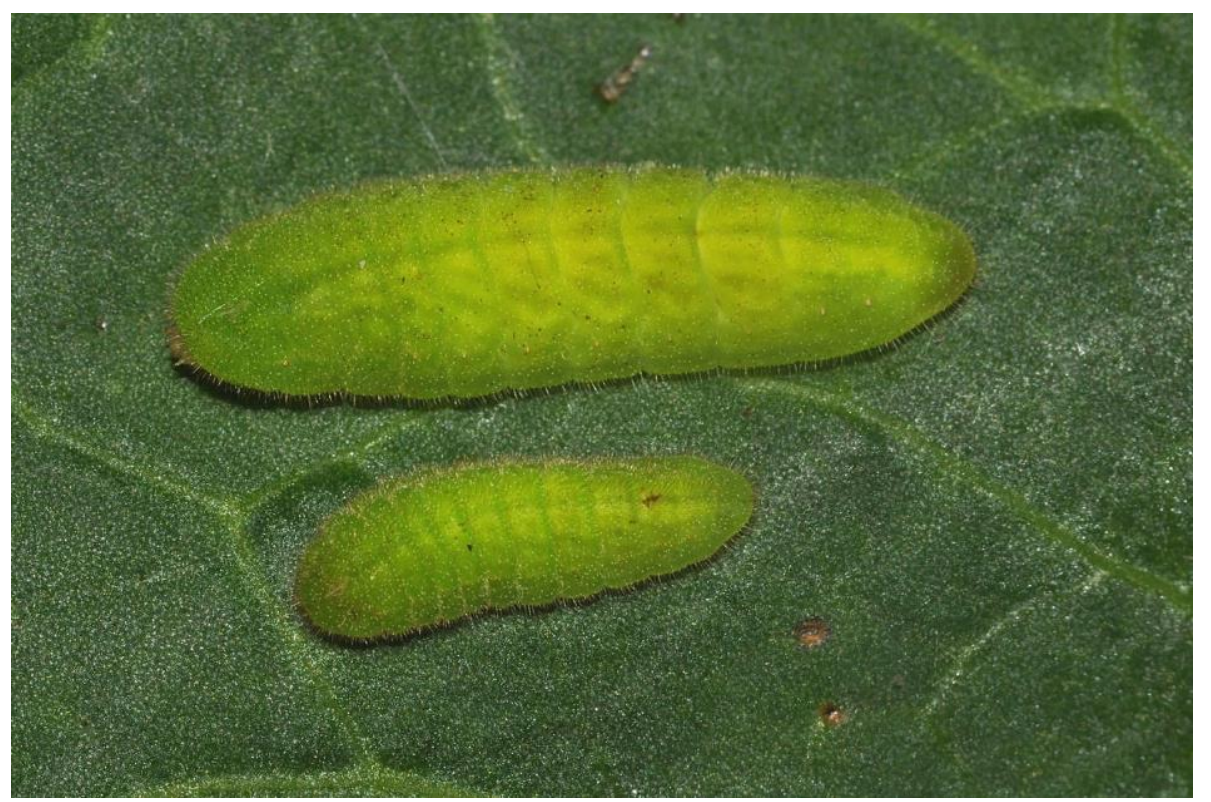

Fig. 1. Comparison of a fully-grown, healthy larva of Lycaena dispar (above) with a larva of similar age parasitized by Hyposoter placidus.

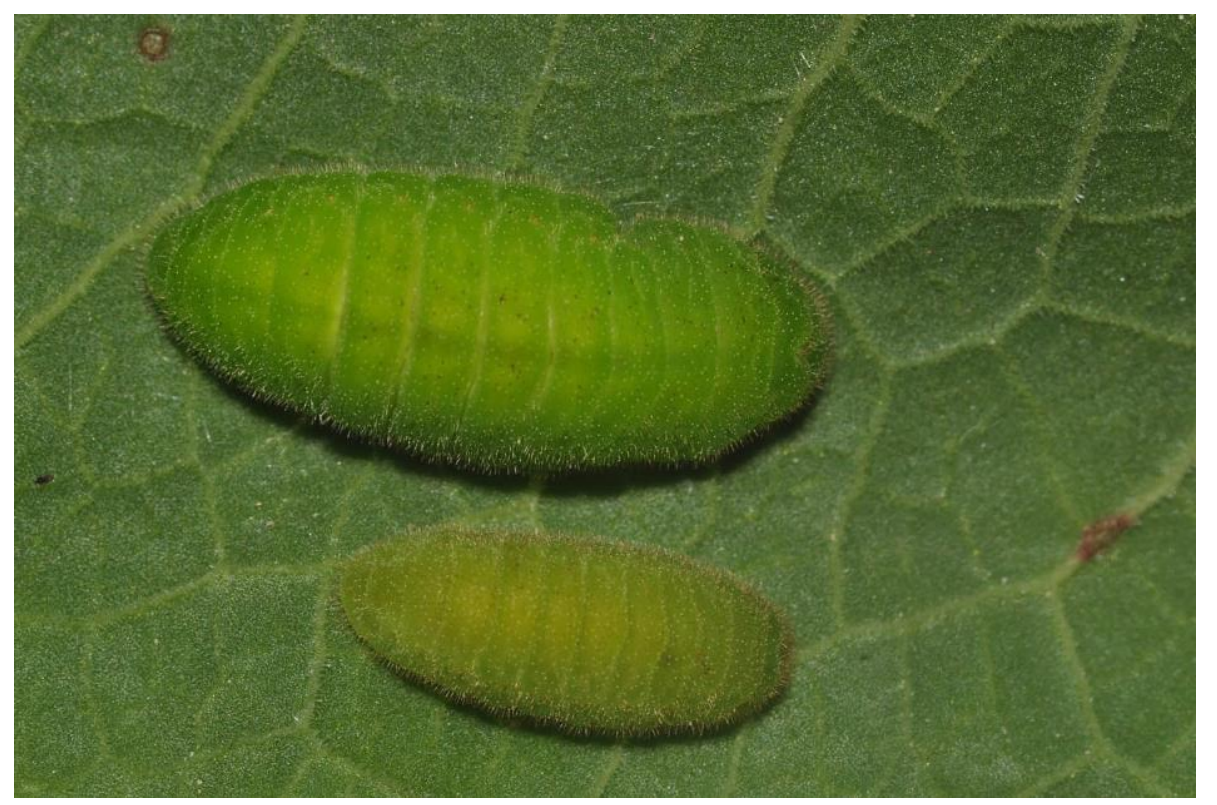

Fig. 2. Prepupa of Lycaena dispar (above) and a parasitized larva shortly before being killed by Hyposoter placidus. 


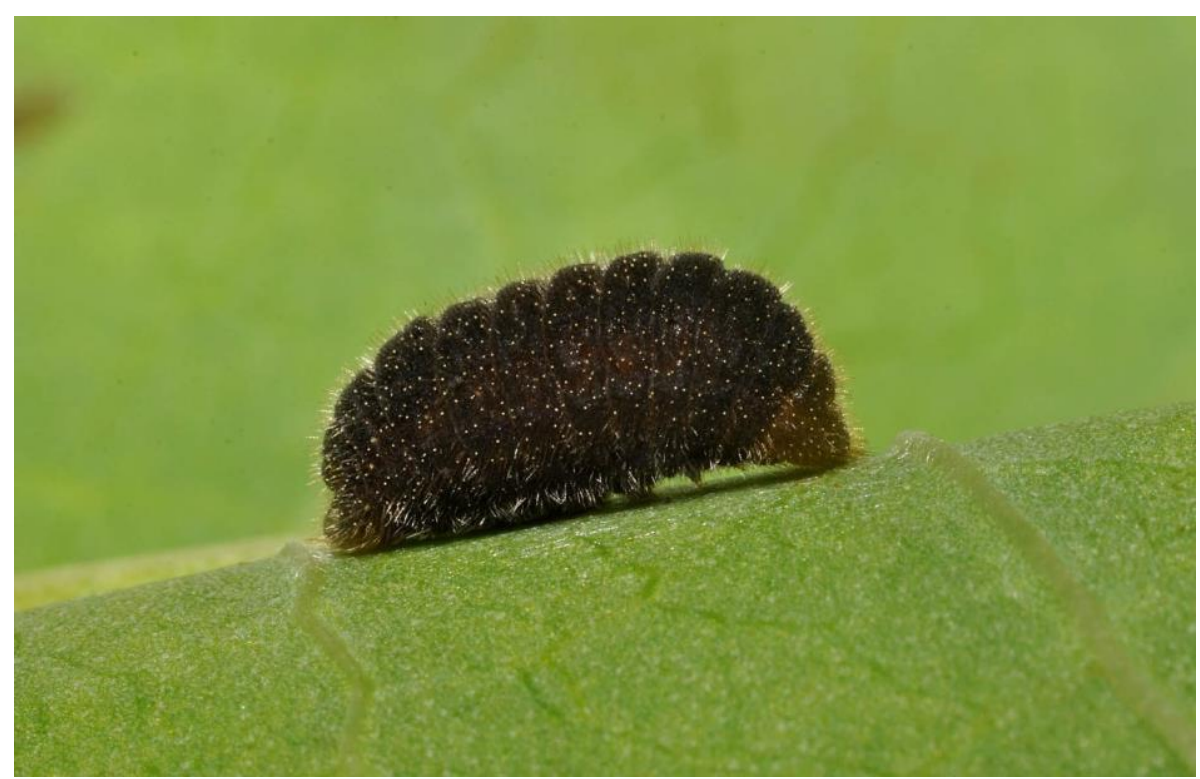

Fig. 3. Larva of Lycaena dispar mummified by Hyposoter placidus.

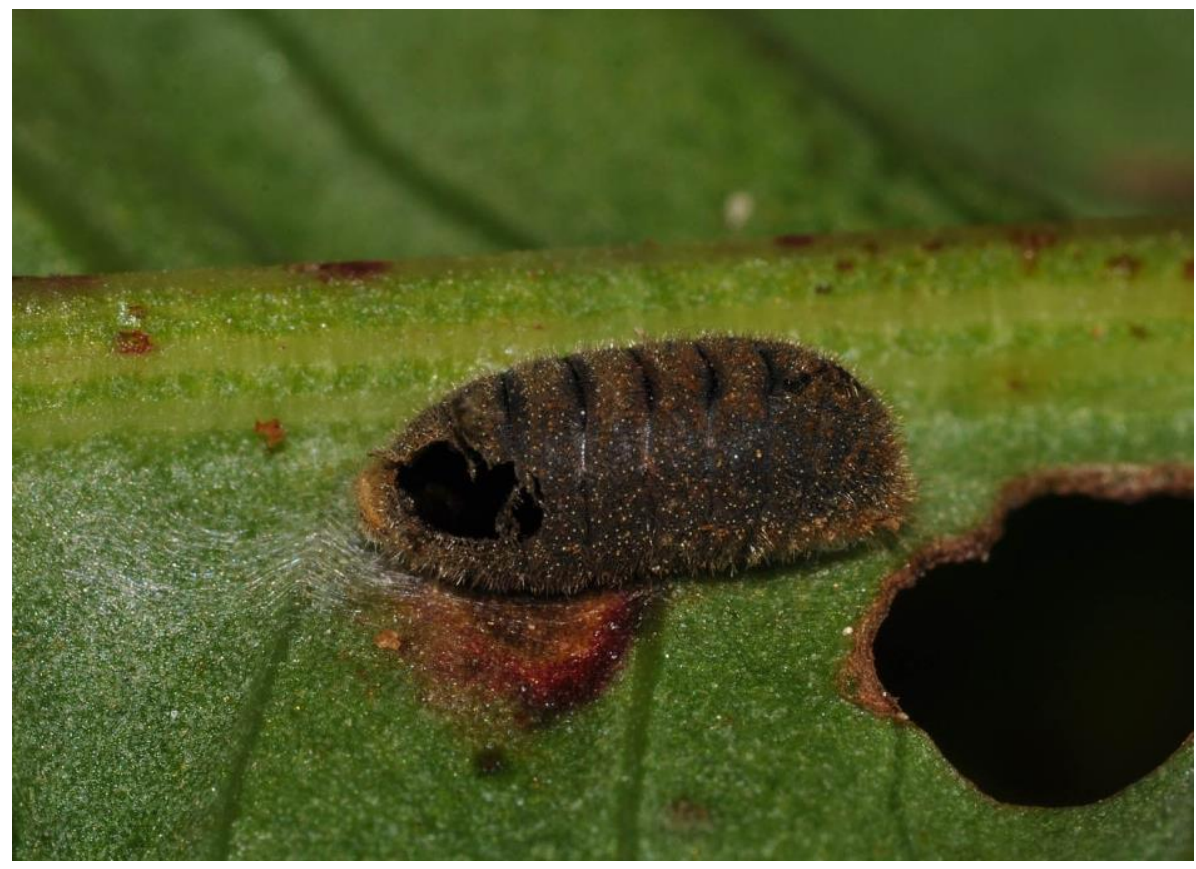

Fig. 4. Mummy of a Lycaena dispar larva after the emergence of Hyposoter placidus. 


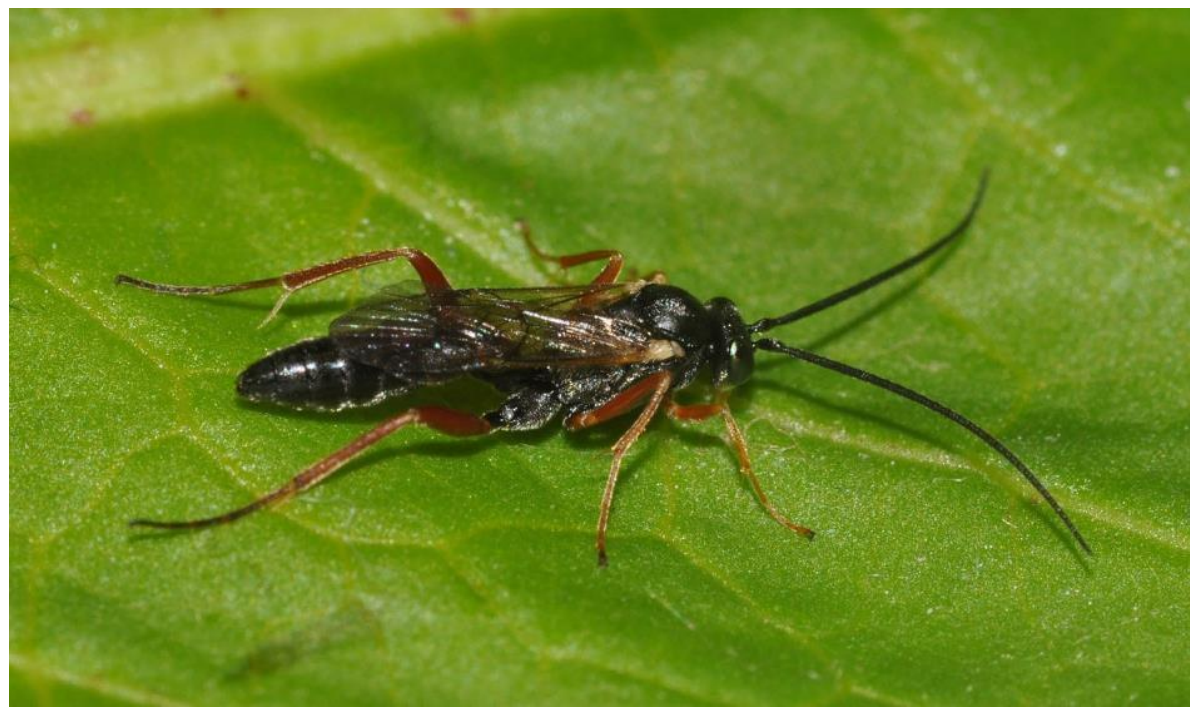

Fig. 5. Male of Hyposoter placidus.

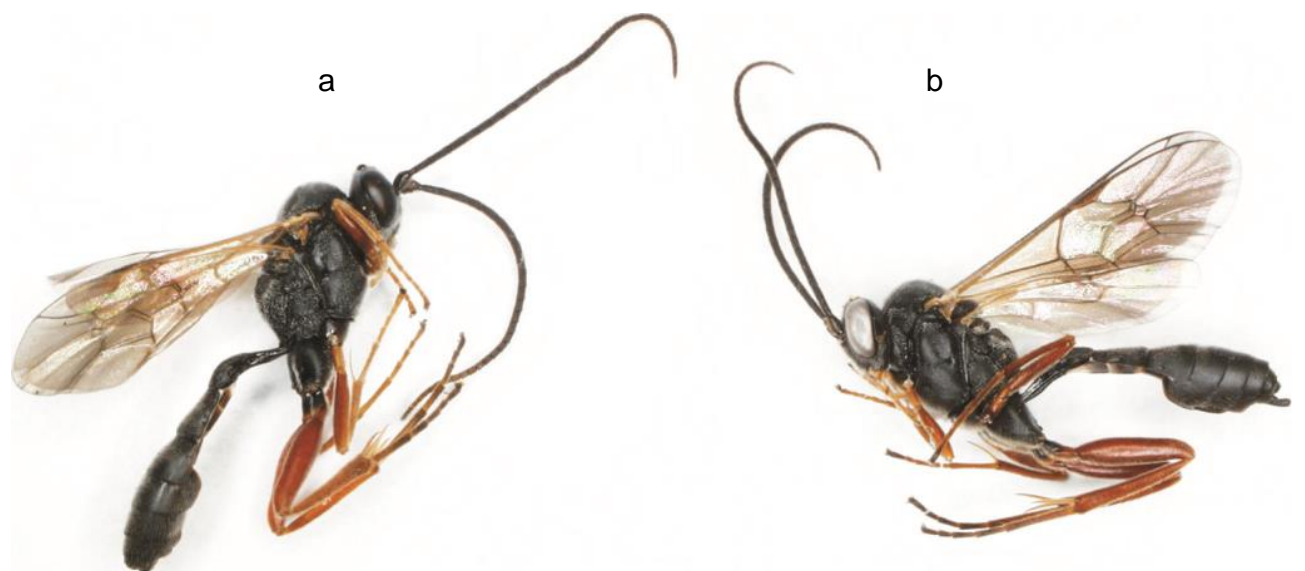

Fig. 6. Male (a) and female (b) of Hyposoter placidus.

It is worth noting here that males of $H$. placidus cannot always be distinguished with certainty from males of $H$. ebeninus (K. HoRSTMANN, unpublished). However, the latter species uses different hosts (SHAW et al. 2009), so there can be little doubt that all the wasps reared in our studies were identified correctly. 


\section{DISCUSSION}

Little is known about the life history of $H$. placidus, but young larvae of L. dispar are probably parasitized before the winter diapause, the parasitoid overwinters within its host (SHAw et al. 2016). However, H. placidus, at least in Poland, is probably double-brooded like its host (SIELEZNIEW 2015), as also suggested by the late summer finding near Gołdap. Other species of the genus Lycaena FABRICIUS, 1807, i.e. L. helle (DENIS \& SCHIFFERMÜLLER, 1775), L. hippothoe (LINNAEUS, 1761) and L. phlaeas (LinNAEUS, 1761), are also mentioned as its hosts (SHAW et al. 2016).

Hyposoter placidus has been recorded so far from Belgium, France, Germany, Ireland, the Netherlands, Spain and the United Kingdom (YU et al. 2012, SHAw et al. 2016). Hence, our records from Poland are the easternmost known localities of the wasp. At the same time $H$. placidus is the only known representative of the genus in Europe parasitizing Lycaena butterflies and one of three species associated with the Lycaenidae family. However, the hosts of the other two, i.e. H. notatus (GRAVENHORST, 1829) and H. caudator HoRSTMANN, 2008, are restricted to a different lycaenid tribe, the Polyommatini (SHAW et al. 2009).

Lycaena dispar is listed in Appendix II of the Habitats Directive. Although rare or extinct in some western European countries, it is widely distributed in central and eastern Europe (PULLIN et al. 1998), even exhibiting a northward expansion (LINDMAN et al. 2015). It is not considered threatened at the continental scale (VAN SWAAY et al. 2010, MAES et al. 2019). Despite being usually recorded in low numbers (SIELEZNIEW 2015), L. dispar in Poland inhabits a variety of open biotopes, ranging from very wet to moderately dry ones; this is probably related wide availabilityof potential larval food plants - Rumex L. species, like $R$. crispus L., $R$. hydrolapathum, $R$. obtusifolius and even the invasive $R$. confertus.

Factors controlling butterfly population size have been little investigated (PULLIN et al. 1995). Most of the known larval parasitoids of $L$. dispar are hymenopterans: apart from $H$. placidus, the ichneumonids Anisobas rebellis WESMAEL, 1845) (Ichneumoninae), Apechtis compunctor (LINNAEUS, 1758) and Pimpla rufipes (MILLER, 1759) (Pimplinae), as well as the braconid Cotesia cuprea (LYLE, 1925) (Microgastrinae) have been recorded (SHAW et al. 2009). Caterpillars are also parasitized by the generalist tachinid fly Phryxe vulgaris (FALLÉn, 1810) (Diptera: Tachinidae), while eggs can be attacked by the idiobiont parasitoid Trichogramma sp. (Hymenoptera: Chalcididae) (Pullin et al. 1995). Our studies suggest that $H$. placidus could be an important natural enemy of $L$. dispar, since $40 \%$ of the caterpillars collected in Białystok were parasitized by this ichneumonid.

Further studies are needed to explore the parasitoid complex of $L$. dispar and to assess the relative impact of $H$. placidus and other species on L. dispar populations. In addition, searching for $H$. placidus on other Lycaena species inhabiting the same areas may provide more knowledge about the biology of this parasitoid and its host preferences. 


\section{ACKNOWLEDGEMENTS}

We thank the Regional Directorate for Environmental Protection in Białystok for issuing the relevant permits for collecting $L$. dispar larvae. We are very grateful to Matthias RIEDEL and Mark SHAW for providing us with a copy of the draft key to the genus Hyposoter, prepared by Klaus HORSTMANN before he died. Two anonymous reviewers made valuable comments on the manuscript.

\section{REFERENCES}

Castelo M.K., van NouhuYs S., CoRley J.C. 2010. Olfactory attraction of the larval parasitoid, Hyposoter horticola, to plants infested with eggs of the host butterfly, Melitaea cinxia. Journal of Insect Science, 10 (1): 1-16.

Harvey J.A., Poelman E.H., Gols R. 2010. Development and host utilization in Hyposoter ebeninus (Hymenoptera: Ichneumonidae), a solitary endoparasitoid of Pieris rapae and P. brassicae caterpillars (Lepidoptera: Pieridae). Biological Control, 53 (3): 312-318.

Lindman L., Remm J., SAKSing K., SÕBer V., Õunap E., TAMmaru T. 2015. Lycaena dispar on its northern distribution limit: an expansive generalist. Insect Conservation and Diversity, 8 (1): $3-16$.

Maes D., Verovnik R., Wiemers M., Brosens D., Beshkov S., Bonelli S., Buszko J., CantúSalazar L., Cassar L.-F., Collins S., Dincă V., Duuric M., Dušej G., Elven H., Franeta F., Garcia-Pereira P., Geryak Y., Goffart P., Gór Á., Hiermann U., Höttinger H., Huemer P., Jakšić P., John E., Kalivoda H., Kati V., Kirkland P., Komac B., Körösi Á., Kulak A., Kuussaari M., L'Hoste L., Lelo S., Mestdagh X., Micevski N., Mihoci I., Mihut S., Monasterio-León Y., Morgun D.V., Munguira M.L., Murray T., Nielsen P.S., ÓlafsSon E., Õunap E., Pamperis L.N., Pavlíč́o A., Pettersson L.B., Popov S., Popović M., Pöyry J., Prentice M., Reyserhove L., Ryrholm N., Šašić M., SAVenkov N., SetTele J., SieleZniew M., Sinev S., Stefanescu C., Švitra G., Tammaru T., TitTsaar A., Tzirkalli E., TzortZaKaki O., VAN SWAay C.A.M., Viborg A.L., Wynhoff I., Zografou K., WARREN M.S. 2019. Integrating national Red Lists for prioritising conservation actions for European butterflies. Journal of Insect Conservation, DOI: 10.1007/s10841-019-00127-z

Medina P., Morales J.J., Budia F., AdÁn A., Del Estal P., Viñuela E. 2007. Compatibility of endoparasitoid Hyposoter didymator (Hymenoptera: Ichneumonidae) protected stages with five selected insecticides. Journal of Economic Entomology, 100 (6): 1789-1796.

Pullin A.S., Balint Z., Balletto E., Buszko J., Coutsis J.G., Goffart P., Kulfan M., Lhonore J.E., Settele J., VAn Der Made J.G. 1998. The status, ecology and conservation of Lycaena dispar (Lycaenidae: Lycaenini) in Europe. Nota Lepidopterologica, 21 (2): 94-100.

Pullin A.S., MCLEAN I.F.G., WebB M.R. 1995. Ecology and conservation of Lycaena dispar: British and European perspectives. [in:] A.S. PULLIN (ed.). Ecology and Conservation of Butterflies. Chapman \& Hall, London, UK, 150-164.

Quicke D.L.J. 2015. The Braconid and Ichneumonid Parasitoid Wasps: Biology, Systematics, Evolution and Ecology. Wiley-Blackwell, Oxford, UK. 
Shaw M.R., Stefanescu C., van Nouhuys S. 2009. Parasitoids of European butterflies. [in:] J. Settele, T. Shreeve, M. KonvičKa, H. van Dyck (eds.). Ecology of Butterflies in Europe. Cambridge University Press, Cambridge, 130-156.

Shaw M.R., Horstmann K., WhifFin A.L. 2016. Two hundred and twenty-five species of reared western Palaearctic Campopleginae (Hymenoptera: Ichneumonidae) in the National Museums of Scotland, with descriptions of new species of Campoplex and Diadegma, and records of fifty-five species new to Britain. Entomologist's Gazette, 67 (3): 177-222.

SiELeZniew M. 2015. Large Copper Lycaena dispar. [in:] M. MaKomaska-Juchiewicz, M. BonK (eds.). Monitoring of animal species. Methodological guide. Part IV. Warszawa, GIOŚ, 44-57. (in Polish)

van Swaay C.A.M., Cuttelod A., Collins S., Maes D., Munguira M.L., Šašíc M., Settele J., VERovnik R., Verstrael T., WARREN M., Wiemers M., Wynhoff I. 2010. European Red List of European Butterflies. Luxembourg, Publication Office of the European Union.

Yu D.S, van Achterberg C., Horstmann K. 2012. World Ichneumonoidea 2011. Taxapad 2012. Flash drive version, Ottawa, Canada.

Received: 20 November 2018

Accepted: 10 January 2019 